Dr Marek Kunasz

Department of Microeconomics

Faculty of Economics and Management

University of Szczecin

\title{
INTELLECTUAL CAPITAL - A NEW SOURCE OF COMPETITIVE ADVANTAGE
}

\begin{abstract}
Changes occurring in environment of organization require a new attitude toward the structure of its capital (taking human, structural, and intellectual capital into account) and toward the measurement of elements that are a major source of the development of its competitiveness and goodwill. Nonetheless, system of reporting does not follow these changes. The paper presents the notion of intellectual capital both employing narrower and wider perspectives as well as historical outline of the way in which the concept of intellectual capital was developed_paying special attention to pioneering works connected with issues relating to measuring intellectual capital and classification of its structuralizing elements (the Konrad Group, K.E.Sveiby, L. Edvisson and M.S. Malone).
\end{abstract}

